\title{
ARTIGO
}

\section{A organização do trabalho, o risco psicossocial e o adoecimento}

Vai te enforcar, vai te entregar, vai te estragar, vai trabalhar...

\section{Odete Pereira Reis ${ }^{2}$}

RESUMO: As transformações pelas quais o mundo do trabalho vem passando, em especial o surgimento de novas tecnologias, a globalização e a reestruturação produtiva, fizeram com que surgissem também novas formas de organização do trabalho. Esse artigo tem como objetivo analisar e realizar reflexões acerca das formas de gestão e organização do trabalho que tem como base, entre outros, a cobrança de metas abusivas e o controle ostensivo dos trabalhadores, com o objetivo de intensificação do trabalho e o aumento contínuo de produtividade, e estudar as consequências para os trabalhadores advindas dessas práticas. Será ainda discutido como o conceito de resiliência vem sendo adotado no contexto organizacional como uma competência a mais que o trabalhador deve ter, e no sentido de não se permitir falhas no sistema. A investigação foca as atividades bancárias e de teleatendimento. A análise será feita a partir de dados de fiscalizações realizadas pela auditoria fiscal do trabalho do extinto Ministério do Trabalho (hoje Ministério da Economia). Serão analisados quatro relatórios de ações fiscais, bem como relatórios de análise de doenças psíquicas relacionadas ao trabalho. Nesse contexto serão discutidos ainda os limites do poder diretivo que, ao adotar essas práticas como legítimas e naturais, na busca por aumento de produtividade e lucro, ignoram questões éticas e os riscos gerados para a saúde dos trabalhadores.

\section{INTRODUÇÃO}

Desde as crises econômicas dos anos 70, as empresas, de modo geral, adaptaram-se para um cenário de maior competição e necessidade de aumento de produtividade. Uma das formas utilizadas para o aumento da produtividade foi a adoção de programas de remuneração variável, atrelados à avaliação de resultados e ao

1 "Vai Trabalhar Vagabundo" (Chico Buarque).

2 Médica do Trabalho e Auditora-fiscal do Trabalho na Superintendência Regional do Trabalho em Minas Gerais. 
atingimento de metas. Esse cenário de cobrança de metas associado a tecnologias cada vez mais eficazes de controle de resultados, potencializa sobremaneira a pressão sobre os trabalhadores, que se sentem "vigiados" e cobrados durante todo o tempo, inclusive, muitas vezes, mesmo fora do horário de trabalho.

Além disso, o estímulo exacerbado à produtividade atrelado à recompensa financeira leva o trabalhador a produzir cada vez mais, extrapolando frequentemente seus limites físicos e mentais ${ }^{3}$.

Nesse cenário de mudanças organizacionais, alguns riscos para os trabalhadores vêm tomando dimensões assustadoras. Em especial, o risco psicossocial.

O risco psicossocial vem sendo foco de estudos e discussões, em especial, a partir da década de 70, e com um incremento a partir do ano de 2000, inclusive com significativo número de suicídios nas empresas europeias ${ }^{4}$, os quais foram atribuídos às situações de trabalho.

Segundo Esteves (2013), o interesse no estudo dos riscos psicossociais deve-se essencialmente às mudanças no mercado que se traduzem num conjunto de novos riscos para o trabalhador. Com a transição de um mercado de indústria para um mercado de serviços, criaram-se grandes multinacionais, sendo exigida mais competição e grandes níveis de produção e rendimento do trabalhador. Ainda, segundo o autor: "Este crescimento das multinacionais tem-se feito acompanhar de uma grande descentralização, outsourcing ${ }^{5}$ e ambientes de trabalho mais flexíveis com grande variação nas condições de trabalho, logo também na exposição a novos riscos ocupacionais". (ESTEVES, 2013, p. 12)

A Agência Europeia para a Segurança e Saúde no Trabalho (EU-OSHA) define os riscos psicossociais como consequências de deficiências na concepção, organização e gestão do trabalho, bem como de um contexto social de trabalho problemático, podendo ter efeitos negativos a nível psicológico, físico e social, tais como estresse relacionado com o trabalho, esgotamento ou depressão.

3 Segundo o Manual de Aplicação da NR 17 (MTE, 2002) "o ser humano é compelido a acelerar sua cadência quando estimulado pecuniariamente ou por outros meios, não levando em conta os limites de resistência de seu sistema musculoesquelético".

4 Segundo Hirata (2013), os suicídios relacionados ao trabalho na França, mas também no Brasil e no Japão, têm sido objeto de atenção, constituindo-se num problema de atualidade científica e social. Na França, fatores como a intensificação do trabalho, a falta de solidariedade, o trabalho em equipe, 0 isolamento social e as práticas de assédio moral e psicológico têm sido apontados como indutores de um aumento significativo dos suicídios relacionados ao trabalho nos últimos anos, sobretudo em grandes empresas como a Renault, a Peugeot e a France-Télécom (DEJOURS; BĖGUE, 2009), mas também em setores como o Ministério do Trabalho francês, no interior do qual suicidou-se recentemente um inspetor do trabalho (COPERNIC, 2011).

5 Processo usado por uma empresa no qual outra organização é contratada para desenvolver uma certa área da empresa. Terceirização.

Laborare. Ano II, Número 3, Jul-Dez/2019, pp. 106-138. ISSN 2595-847X. https://trabalhodigno.org/laborare DOI: https://doi.org/10.33637/2595-847x.2019-35 
Importante ressaltar que o risco psicossocial no trabalho não "surgiu" recentemente. Vale lembrar que, já em 1956, o médico francês Le Guillant publicou estudo sobre o trabalho das telefonistas, em que ele associa a forma de organização do trabalho com o que ele chamou de "síndrome geral da fadiga nervosa". Interessante ainda ressaltar que o autor considerou o trabalho como causa do adoecimento psíquico das trabalhadoras, e não somente como fator desencadeador.

Enfim, o que vem ocorrendo, na verdade, é um "interesse"7 maior pelo tema em tempos mais recentes devido ao significativo aumento de doenças psíquicas relacionadas ao trabalho ${ }^{8}$ decorrentes das mudanças ocorridas no mundo do trabalho.

A primeira parte do artigo aborda como a presença dos riscos psicossociais vem causando sofrimento e afetando a saúde mental dos trabalhadores. Será discutida a questão da invisibilidade dos fatores de risco psicossociais, assim como das doenças psíquicas, que, somada a uma suposta "subjetividade", resulta em uma abordagem inadequada ou em ausência de abordagem dos mesmos. Será ainda discutido como o conceito de resiliência vem sendo utilizado nas organizações.

Na segunda parte, a partir de análises de relatórios de fiscalizações realizadas pela auditoria fiscal do trabalho, em Minas Gerais, em empresas de teleatendimento, nos anos de 2017, 2018 e 2019, e uma fiscalização em um banco, em 2018, será discutido como são diagnosticados os fatores de riscos psicossociais nas práticas de gestão adotadas pelas empresas ${ }^{9}$.

E por fim, no item Considerações Finais, será discutido o papel da auditoria físcal do trabalho na análise da organização do trabalho visando o levantamento dos riscos psicossociais e a configuração do assédio moral e, por último, as dificuldades

\begin{abstract}
6 A "Síndrome Geral da Fadiga Nervosa" foi descrita como um quadro com sintomatologia variável, como fadiga nervosa, alterações do humor, distúrbios do sono, manifestações somáticas como angústias, palpitações, cefaleias etc. $O$ autor relata que as "condições de trabalho que o progresso técnico tende a instaurar, cada vez mais", resulta em aceleração das ações e das cadências, e exigência de maior atenção, precisão e rapidez.

7 Segundo Costa e Santos (2013): O interesse recente pelos riscos psicossociais corresponderá, então, mais provavelmente "ao despertar" para a sua existência do que, propriamente, ao seu efetivo aparecimento, até porque, havendo quem coloque a sua emergência no ano 2000, esta não é uma realidade da última década. Para alguns autores, surgiu por volta dos anos 70, fruto das profundas alterações no mundo do trabalho (VALLÉRY; LEDUC, 2012), mas já no início do século XX se efetuavam estudos que recaíam, por exemplo, sobre os efeitos psicológicos na fadiga (STRONG; EDWARD, 1914, p. 42).

8 Segundo dados do Ministério da Saúde, os transtornos mentais e comportamentais são a terceira maior causa de afastamento do trabalho, e quando se fala em auxílios pagos relacionado ao trabalho, os números são ainda mais expressivos. Reações ao "stress" grave e transtornos de adaptação, episódios depressivos e outros transtornos ansiosos causaram 79\% dos afastamentos no período de 2012 a 2016. Disponível em: http://www.blog.saude.gov.br. Acesso em: 19 jun. 2019.

9 Todos os dados encontram-se registrados no Sistema Federal de Inspeção do Trabalho- SFIT, programa desenvolvido pelo SERPRO (Serviço Federal de Processamento de Dados). Trata-se de um sistema informatizado que opera um banco de informações a partir do conjunto de dados produzidos por todas as ações fiscais realizadas em todo o país, ou seja, ele reúne todos os dados da inspeção do trabalho.
\end{abstract}

Laborare. Ano II, Número 3, Jul-Dez/2019, pp. 106-138. ISSN 2595-847X. https://trabalhodigno.org/laborare DOl: https://doi.org/10.33637/2595-847x.2019-35 
encontradas em se impor limites a essas práticas, frente à tolerância e mesmo naturalização das mesmas.

\section{OS FATORES DE RISCO PSICOSSOCIAL, O ADOECIMENTO MENTAL E A INVISIBILIDADE}

"Se, por um lado, necessitamos do trabalho humano e de seu potencial emancipador, devemos também recusar o trabalho que explora, aliena, e infelicita o ser social." (ANTUNES, 2013)

Os dados sobre adoecimento mental são cada vez mais alarmantes, inclusive aqueles relacionados ao trabalho.

Na Europa, o estresse ocupa a segunda posição entre os problemas de saúde relacionados ao trabalho, afetando cerca de 40 milhões de pessoas (BRASIL, 2017). No Brasil, os transtornos mentais e comportamentais foram a terceira causa de incapacidade para o trabalho, considerando a concessão de auxílio-doença e aposentadoria por invalidez, no período de 2012 a 2016, segundo a Previdência Social.

Transtornos de humor, como a depressão, transtornos neuróticos (síndrome do pânico e estresse pós-traumático, por exemplo) e o uso de substâncias psicoativas, como o álcool e as drogas, são os principais transtornos mentais que causam incapacidade para o trabalho no Brasil. Essas patologias, comumente, se desencadeiam a partir do chamado estresse ocupacional, ocasionado por fatores como cobrança abusiva de metas e assédio moral (BRASIL,2016).

Ao contrário de outros fatores de risco presentes no ambiente de trabalho (como ruído, poeiras etc.), os fatores de risco psicossociais, além de invisíveis, não são passíveis de medições através de aparelhos. O que também ocorre em relação aos adoecimentos ou acometimentos psíquicos, que não são diagnosticáveis através de exames laboratoriais ou por aparelhos. Dessa forma, ambos são cercados por uma certa invisibilidade, que, ousamos dizer, serve, muitas vezes, como pretexto ou mesmo oportunidade para o seu escamoteamento ou para a sua não abordagem.

Dessa forma, é necessário desmistificar alguns conceitos sobre os fatores de risco psicossociais no trabalho, assim como sobre as doenças a eles relacionadas.

\section{O TRABALHO E OS FATORES DE RISCO PSICOSSOCIAL}

O mundo do trabalho pós-globalização passou por mudanças importantes, com reflexos diretos nos processos de trabalho e na saúde do trabalhador.

Laborare. Ano II, Número 3, Jul-Dez/2019, pp. 106-138. ISSN 2595-847X. https://trabalhodigno.org/laborare DOl: https://doi.org/10.33637/2595-847x.2019-35 
Segundo Lacaz (2008), na esfera econômica, a globalização abrange as relações de produção, financeiras e comerciais envolvendo a perspectiva da reorganização das estruturas produtivas e do aumento de fluxos comerciais, o que se acompanha do desenvolvimento tecnológico. Essa reorganização produtiva e comercial vem para garantir a referida expansão, ao lado da oligopolização empresarial e da expansão da atividade das corporações transnacionais, o que é acompanhada da desregulamentação dos mercados financeiros, de comunicação e de transportes.

E é desse contexto que surgem as novas formas de gestão da produção pautadas, em especial, na intensificação do trabalho, imposição de metas de produtividade, com um aprofundamento dos modelos disciplinares e de controle, características essas que criam um terreno fértil para o assédio moral organizacional ${ }^{10}$.

As formas de gestão e organização do trabalho que se fundamentam, em especial, na gestão "pelo estresse" e "pelo medo" (ambas rotineiramente verificadas nas empresas de teleatendimento, objeto desse estudo) se apresentam como práticas "necessárias"11 para se atingir os objetivos empresariais, como a lucratividade, a produtividade e a eficiência, o que torna o seu combate mais difícil.

Segundo Soboll e Horst (2013), esses elementos ligados às estratégias de gestão estão presentes no ambiente de trabalho de forma naturalizada, não sendo questionados pelos próprios trabalhadores, os quais internalizaram a lógica da excelência: "Diante disso, muitas práticas de assédio moral podem ser justificadas e tidas como legítimas tendo em vista esta matriz de valores organizacionais centrados na competição, na superação e nos resultados de curto prazo" (SOBOLL; HORST, 2013, p. 191).

A chamada "gestão por estresse" tem o objetivo de melhorar o desempenho, a eficiência ou a rapidez no trabalho e não pretende destruir o trabalhador, embora as consequências na saúde possam ser desastrosas (SOBOLL, 2008). Ela tem como características, segundo a mesma autora, cobranças constantes, supervisão exagerada, comparações do desempenho dos trabalhadores, ranking de produtividade, metas muito exigentes de produtividade, e-mails de comparação de resultados, e prazos inadequados às exigências das tarefas são situações comuns quando há predomínio de estratégias de gestão por estresse.

10 Os modos de gestão do trabalho atuais se apresentam como muito patógenos, porque o cinismo, por exemplo, um dos instrumentos admissíveis nesses modelos de gestão, não é nem mesmo mais dissimulado. $O$ cinismo tornou-se um valor positivo. São organizações do trabalho que prescrevem, também, o medo em seu guia de gestão. $E$ isso é totalmente novo. $E$ totalmente insuportável. $E$ gera patologias mentais que crescem junto com os suicídios no próprio local de trabalho (MERLO, MACEDO 2016).

11 Nesse sentido, segundo Soboll (2008), o assédio organizacional encontra-se camuflado no discurso economicista, como inerente ao trabalho no capitalismo globalizado e competitivo. Segundo a autora, é na política organizacional fundada na violência que se encontram as sementes geradoras das situações extremas de violência psicológica. Até mesmo comportamentos típicos de assédio moral são, por vezes, mediados por justificativas que seriam bem vistas quando se consideram apenas os objetivos economicistas.

Laborare. Ano II, Número 3, Jul-Dez/2019, pp. 106-138. ISSN 2595-847X. https://trabalhodigno.org/laborare DOl: https://doi.org/10.33637/2595-847x.2019-35 
Já a "gestão por medo" utiliza a ameaça, implícita ou explícita, como estímulo principal para gerar adesão do trabalhador aos objetivos organizacionais. Segundo a autora, a ameaça de perder o cargo, o emprego ou de ser exposto a constrangimentos favorece condutas de obediência e de submissão, mas também condutas agressivas:

Por medo de ser incompetente, perder o cargo, não conseguir progredir na carreira, perder o emprego e tornar-se excluído da sociedade, o trabalhador ataca antes de ser atacado e acaba por adotar comportamentos hostis e antiéticos, deteriorando as relações e o clima de trabalho. (SOBOLL, 2008, p. 82)

Dessa forma, pode-se dizer que existe uma tolerância a esses métodos de gestão utilizados, a despeito das graves repercussões na saúde dos trabalhadores. Pouco se vê de questionamentos sobre eles, seja por parte dos profissionais de saúde e segurança do trabalho, seja dos órgãos reguladores, que ainda realizam um trabalho incipiente ou de pouco impacto.

Araújo (2016) chama atenção para a omissão dos órgãos fiscalizadores ao tratar de assédio moral:

A violência psicológica (assédio moral) contou sempre com a reticência dos órgãos de físcalização em se imiscuir nas decisões de direção da empresa [...]. A timidez da verificação de legitimidade dos atos empresariais por certo tempo assegurou a tranquilidade a essa prática empresarial abusiva. (ARAÚJO, 2016, p.141)

Os próprios trabalhadores, muitas vezes, não percebem o que está ocorrendo como algo anormal, ao contrário, visualizam aquela situação como necessária e própria da atividade $^{12}$. O que nos leva à necessidade de se falar sobre a resiliência.

\section{RESILIÊNCIA}

O conceito de resiliência é oriundo da física e significa a propriedade que um corpo possui de recuperar a sua forma original após sofrer um choque ou uma deformação.

No contexto das organizações, a resiliência se refere à capacidade das pessoas de manter ou retornar ao seu equilíbrio emocional após sofrer situações de estresse ou pressão ${ }^{13}$.

12 Nos relatórios de fiscalização, há registro de frases dos trabalhadores sobre esse tema, como: "No teleatendimento é assim mesmo [...]" ou de uma supervisora: "O trabalhador tem de ter esse perfil, tem de 'aguentar', senão é trocado".

13 Ao falar sobre situações de estresse, importante trazer à tona o conceito de coping, dada a sua íntima relação com a resiliência. Coping é definido em geral como o conjunto das estratégias utilizadas pelas pessoas para adaptarem-se a circunstâncias adversas ou estressantes. Segundo Taboada N. G., Legal, E. J, Machado, N.

Laborare. Ano II, Número 3, Jul-Dez/2019, pp. 106-138. ISSN 2595-847X. https://trabalhodigno.org/laborare DOI: https://doi.org/10.33637/2595-847x.2019-35 
Segundo Cimbalista (2010), mesmo se encontrando, muitas vezes, no seu limite, o trabalhador supera o cansaço, a raiva, e submete-se à realidade de seu cotidiano, contudo, transformando-se e fortalecendo-se através dessa transformação. Esse movimento ambíguo entre revolta e resignação é o cerne da resiliência, quando o indivíduo reflete sobre situações adversas e se adapta para prosseguir.

Importante ressaltar que o conceito de resiliência se encontra em desenvolvimento na comunidade científica internacional, nos últimos anos, logo, a intenção aqui, muito longe de se esgotar o tema, é realizar uma breve reflexão sobre o tema, tendo em vista a frequência com que nos deparamos com situações que apresentam relação com esse conceito, como aquelas que serão relatadas a seguir.

Atualmente, o conceito de resiliência vem sendo muito exaltado nos discursos organizacionais, de forma positiva, no sentido de um perfil ou uma competência a mais que o trabalhador deve possuir. Muito se ouve sobre ser essa a competência mais importante no mundo do trabalho, do século XXI.

Sobre isso, Cimbalista (2006) diz que a ênfase dada ao lado 'positivo' da atitude resiliente no contexto das empresas decorre do chamado 'novo perfil' do trabalhador:

Este perfil exige uma reação positiva, no sentido de se enfrentar situações de difícil solução, resolvê-las e recobrar forças para continuar o seu trabalho. $\mathrm{O}$ trabalhador precisa se dobrar e desdobrar perante diferentes situações adversas, seja na resolução de problemas em nível individual ou grupal, no atendimento a clientes internos ou externos, no cumprimento das metas, na sua constante qualificação e atualização técnica, enfim, o trabalhador deve ser habilidoso e superar obstáculos. (CIMBALISTA, 2006, p. 17)

Para as organizações é muito importante que o sujeito capte essa mensagem, pois ao levá-la para seu campo subjetivo, ele irá acreditar que, ao enfrentar todas as adversidades e crises, será recompensado, reconhecido, promovido, tornando-se um verdadeiro "vencedor" (VIEIRA; OLIVEIRA, 2017 ${ }^{14}$ ).

Ainda segundo esses mesmos autores, as sociedades capitalistas tendem a valorizar excessivamente os atributos que cada indivíduo vem a desempenhar no contexto organizacional, visando sempre à precisão e não permitindo nenhum tipo de falha no processo.

et al (2006), o coping tem foco na maneira, na estratégia utilizada para lidar com a situação, independentemente do resultado obtido, enquanto a resiliência encontra-se relacionada ao resultado da estratégia (ou estratégias) utilizada, que seria uma adaptação bem sucedida do sujeito frente às adversidades. 14 Vieira e Oliveira (2017) realizaram interessante pesquisa sobre resiliência no contexto das organizações, analisando 59 trabalhos sobre o tema publicados no período de 1999 a 2014, com a realização de uma comparação entre as teorias funcionalista e crítica relacionadas ao conceito de resiliência.

Laborare. Ano II, Número 3, Jul-Dez/2019, pp. 106-138. ISSN 2595-847X. https://trabalhodigno.org/laborare DOI: https://doi.org/10.33637/2595-847x.2019-35 
Os esforços para se manter equilibrado e indiferente às adversidades que, muitas vezes, inclusive, ocorrem de forma frequente (como na atividade de teleatendimento, onde se é comum ter de lidar com situações de grande estresse), podem trazer uma série de consequências para os trabalhadores, podendo ser mais um fator de adoecimento.

Durante realização de análise de doença psíquica em empresa de teleatendimento, no ano de 2019, em depoimento gravado pela auditoria fiscal do trabalho, o trabalhador em questão relata que ligações "estressantes" são rotina em seu trabalho, mas ressalta uma situação que o afetou muito, agravando seu estado de saúde. Durante o depoimento, o trabalhador, que se encontrava em estado de choro quase constante, relata um atendimento em que o cliente entrou em contato para reclamar de algo sobre seu cartão de crédito. O cliente se encontrava muito descontrolado, agredindo o trabalhador verbalmente de forma contínua. Assim que a ligação foi encerrada, o trabalhador colocou uma pausa de poucos minutos no sistema para que ele não recebesse outras ligações. O trabalhador ressalta ainda "saber que estava errado" ao fazer isso, uma vez que a empresa não permite realização de pausas não programadas, no entanto, ele se encontrava muito abalado e precisava se recuperar antes de continuar a realizar seu serviço.

Alguns dias depois, quando seus superiores perceberam que ele colocou uma "pausa indevida", ele foi chamado na sala de um dos gestores e recebeu uma advertência devido a isso. Segundo a fala do mesmo:

Quando eu entrei na sala dela (da gestora) eu fui extremamente hostilizado e humilhado... (Disse que) eu estava dando prejuizo para a empresa, que eu estava sendo irresponsável, que a minha obrigação é atender, não importa, não importa o tipo de ligação, que eu tenho que ter qualidade... E foi falando, e me ameaçando: "Você sabia que eu posso te mandar embora por justa causa? Você sabe que eu posso te mandar embora por justa causa?”.

Importante lembrar que o item 5.4.5 do Anexo II da NR 17 prevê que "devem ser garantidas pausas no trabalho imediatamente após operação onde haja ocorrido ameaças, abuso verbal, agressões ou que tenha sido especialmente desgastante, que permitam ao operador recuperar-se e socializar conflitos e dificuldades com colegas, supervisores ou profissionais de saúde ocupacional, especialmente capacitados para tal acolhimento".

$\mathrm{Na}$ rotina das fiscalizações, o que se verifica é que esse importante item da norma regulamentadora não é cumprido, não havendo previsão para que esse tipo de pausa seja utilizado, e a maioria dos trabalhadores sequer conhece tal dispositivo.

Laborare. Ano II, Número 3, Jul-Dez/2019, pp. 106-138. ISSN 2595-847X. https://trabalhodigno.org/laborare DOI: https://doi.org/10.33637/2595-847x.2019-35 
Já em outra empresa, a fiscalização verificou também uma aplicação de medida disciplinar pelo fato de a trabalhadora ter encerrado uma chamada em que ela estava sendo agredida pelo cliente. Tratava-se de um call center de uma concessionária de energia, e o cliente ligou por estar sem energia há alguns dias. $\mathrm{O}$ cliente estava muito descontrolado, xingando a trabalhadora, utilizando, inclusive, palavras de baixo calão, conforme consta na própria advertência.

Veja cópia de parte do documento, abaixo. Os nomes dos trabalhadores e da empresa foram preservados.

Tipo de medida: ADVERTÊNCIA

Venho por meio desta, informar que, no dia 02/11/2016 V.Sa. praticou o seguinte ato em desacordo com as normas internas da empresa:

Colaboradora encerra a chamada de cliente que alega estar 06 dias sem energia. Cliente nervoso cita palavra de baixo calão, não direcionado à cr. A atendente toma para si o desagravo, avisa ao cliente que a ligação poderá ser transferida/encerrada. Solicitante informa que as palavras não são direcionados a ela mas sim aos serviços não atendidos pela concessionária de energia e novamente usa palavra de baixo calão. Mesmo ciente que tais desabafos não eram direcionadas à colaboradora, a mesma transfere a ligação para o encerramento da chamada. A atendente deveria: agir com empatia com o cliente cuja instalação estava há seis dias sem energia; entender que os palavras de baixo calão não foram a ela direcionados; gerar a solicitação para atendimento ao cliente.

Dados da ligação: tel: 38999860006, data: 02/11/2016; protocolo de atendimento: 2001865955, ETI; 382517 .

Como é de Vosso conhecimento, tal procedimento não pode ser aceito, conforme vastamente informado, tanto pessoalmente, quanto em reuniões coletivas com a sua equipe, bem como de acordo com o treinamento que Ihe foi ministrado.

Então, de acordo com as instruções que lhe foram passadas anteriormente, V.Sa. deveria ter agido da seguinte forma:

O colaborador deve atender o cliente com paciência e cortesia demonstrando boa vontade em resolver a demanda do cliente no primeiro contato, seguindo os procedimentos previstos nas resoluções,

treinamentos, Pasta do Atendente e POP.

Segundo texto contido no documento acima:

Cliente nervoso, cita palavras de baixo calão, não direcionado à (colaboradora). Atendente toma para si o desagravo, avisa para o cliente que a ligação poderá ser transferida e encerrada. Solicitante informa que as palavras não são direcionadas a ela, mas sim aos serviços não atendidos pela concessionária de energia e novamente usa palavra de baixo calão. Mesmo ciente que tais desabafos não eram direcionados à colaboradora, a mesma transfere a ligação para o encerramento da chamada. A atendente deveria: agir com empatia com o cliente cuja instalação estava há seis dias sem energia, entender que as palavras de baixo calão não foram a ela direcionadas, gerar a solicitação para o atendimento do cliente.

Laborare. Ano II, Número 3, Jul-Dez/2019, pp. 106-138. ISSN 2595-847X. https://trabalhodigno.org/laborare DOl: https://doi.org/10.33637/2595-847x.2019-35 
É possível perceber no texto que, por estar sendo agredida, a trabalhadora avisa para o cliente que a ligação poderá ser transferida ou encerrada, e tenta ainda dar prosseguimento ao atendimento. No entanto, como os xingamentos persistem, ela encerra a ligação.

Pode-se verificar que, em ambos os casos, a aplicação de medida disciplinar ocorreu devido às reações de ambos os trabalhadores frente às situações de tensão ou estresse pelas quais eles passaram. Em um dos casos o trabalhador encerrou a ligação, e no outro caso, realizou uma pequena pausa.

Para Vieira e Oliveira (2017), ao se pensar na resiliência como um mecanismo de defesa, tanto na vida pessoal quanto no ambiente de trabalho, é natural e instintivo que o indivíduo venha a fazer uso desses mecanismos de defesa, consciente ou inconscientemente, para que se mantenha no controle e possa enfrentar as situações de desafio. Todavia, chamam atenção para o fato de que o esforço para que se mantenham em constate equilíbrio emocional e resiliente, diante de situações desafiadoras, geralmente é muito elevado.

Cimbalista (2006) também chama atenção para esse aspecto ao dizer que esta característica intrínseca aos indivíduos, ou seja, de transformar a adversidade e retornar como um elástico que, após ser esticado, volta ao estado inicial, é nos humanos, variável. Segundo a autora, a atitude resiliente não pode ser vista como um atributo fixo do indivíduo, se as circunstâncias mudam, a resiliência se altera. E conclui: "Isto quer dizer que, como o elástico, metáfora usada para a resiliência, a atitude resiliente pode trazer ganhos, mas também perdas para o indivíduotrabalhador" (CIMBALISTA, 2006, p. 2) ${ }^{15}$.

Para Vieira e Oliveira (2017), o conceito de resiliência aplicado no contexto organizacional, com o intuito de que tudo seja tolerado e suportado pelos indivíduos, dificulta a consciência das relações de exploração e de injustiça; estimula a alienação, a insensibilidade e a quebra do espírito da coletividade:

A relação conflituosa entre o prescrito, o real do trabalho presente na rotina do sujeito e o sofrimento gerado por ela são menos importantes para a organização quando o foco está somente no aumento de produtividade, de lucro e de liderança no mercado (VIEIRA; OLIVEIRA, 2017, p. 417)

E, por último, Kompier e Kristensen (2000), citados por Lucca S. R., Sobral R. C. (2017) apontam que as intervenções no nível das empresas frente à presença de riscos

15 O termo indivíduo-trabalhador, cunhado pela autora, segundo a mesma "refere-se ao ser humano que vive uma situação real de trabalho, tratada também de forma afetiva, com emoção, sentimentos, um estado da alma, pensamento e corpo deste ser dotado de subjetividade".

Laborare. Ano II, Número 3, Jul-Dez/2019, pp. 106-138. ISSN 2595-847X. https://trabalhodigno.org/laborare DOl: https://doi.org/10.33637/2595-847x.2019-35 
psicossociais podem ser primárias (redução de estressores), secundárias (redução de estresse percebido pelo indivíduo e suas estratégias de enfrentamento - coping, ou de sinais de adoecimento) e terciárias (redução das consequências de longo prazo do estresse laboral e a reinserção dos trabalhadores adoecidos).

Dessa forma, devemos lembrar que, o que se espera, prioritariamente, em relação aos riscos à saúde dos trabalhadores, presentes nos ambientes de trabalho, é uma intervenção primária, ou seja, nos ambientes de trabalho, de modo que a organização do trabalho seja adequada às características psicofisiológicas dos trabalhadores, medida essa, inclusive, prevista em norma regulamentadora ${ }^{16}$.

\section{SOBRE A "SUBJETIVIDADE" DO ADOECIMENTO MENTAL}

Tendo em vista as práticas de gestão citadas acima (cujos exemplos serão apontados no tópico a seguir), faz-se necessário falar sobre as consequências das mesmas sobre a saúde dos trabalhadores.

Além de todo o estigma ${ }^{17}$ associado aos transtornos mentais, há ainda uma grande culpabilização do indivíduo acometido por esse tipo de transtorno, quando o indivíduo é visto como o responsável por seu adoecimento. Ou seja, o transtorno mental por si só, sem levarmos em consideração a relação do mesmo com o trabalho, já é um terreno delicado, sendo que, muitas vezes, a busca por ajuda profissional ocorre de forma tardia, retardando, dessa forma, o diagnóstico e o tratamento.

Essas questões que envolvem o adoecimento mental, em conjunto com o fato de se considerar como "naturais" (conforme discutido anteriormente) as práticas abusivas e agressivas de gestão do trabalho, prejudicam o estabelecimento do nexo entre o trabalho e o adoecimento.

Silva, Bernardo e Souza (2016) cita o conceito de "desgaste mental" desenvolvido por Seligmann-Silva, criado para analisar o processo de saúde/doença psíquica relacionado ao trabalho. Faz-se uma integração do processo biopsicossocial saúde/doença, correlacionando poderes e cargas de trabalho vivenciadas pelos trabalhadores. Dessa forma, para a autora o conceito de desgaste mental seria:

\footnotetext{
16 Segundo item 17.6.1 da NR 17: $A$ organização do trabalho deve ser adequada às características psicofisiológicas dos trabalhadores e à natureza do trabalho a ser executado.

17 Segundo (ROCHA, F. L.; HARA, C.; PAPROCKI, J., 2015), "o estigma associado à doença mental é dos mais importantes e difíceis obstáculos para a recuperação e reabilitação do indivíduo; afeta negativamente o tratamento; nega oportunidade de trabalho; impede a autonomia e a realização de objetivos de vida. É capaz de prejudicar a qualidade de vida, inclusive da família e da equipe de saúde que lida com as doenças psiquiátricas. A discriminação pode ser tão incapacitante quanto a própria doença. Além disso, viver em ambiente estigmatizante frequentemente acarreta $\circ$ autoestigma, que junto com $\circ$ estigma são dois obstáculos fundamentais à integração social e à vida plena em sociedade".
}

Laborare. Ano II, Número 3, Jul-Dez/2019, pp. 106-138. ISSN 2595-847X. https://trabalhodigno.org/laborare DOl: https://doi.org/10.33637/2595-847x.2019-35 
O desgaste é visualizado como produto de uma correlação desigual de poderes impostos sobre o trabalho e sobre o trabalhador, acionando forças que incidem no processo biopsicossocial saúde-doença. Ou melhor, uma correlação de poderes e forças em que o executante do trabalho torna-se perdedor. (SILVA, BERNARDO; SOUZA, 2016, p. 3)

A autora cita que essas condições de trabalho podem conduzir a sérios problemas relacionados à saúde mental, como síndrome de burnout ${ }^{18}$, depressão, suicídio, abuso de álcool e drogas, psicossomatização, estresse, fadiga, entre outros.

Não é a intenção deste artigo aprofundar-se na gênese do adoecimento mental relacionado ao trabalho. Porém, faz-se importante ressaltar a questão da alegada subjetividade dos sintomas como mais um fator dificultador na realização do diagnóstico.

Os transtornos mentais realmente não são diagnosticáveis por meio de exames. O diagnóstico é feito a partir do relato do paciente. Porém, vale ressaltar que esses tipos de transtornos, como por exemplo, depressão, ansiedade, síndrome do pânico etc., assim como inúmeros outros tipos de doenças, são muito bem descritos na medicina. Logo, a partir da anamnese, que constitui parte fundamental de qualquer consulta médica, o médico possui plenas condições de estabelecer o diagnóstico do acometimento ou doença em questão

Muito pertinentes as colocações de Penido e Perone (2013) ao discorrerem sobre as argumentações de parcela da doutrina jurídica de que as definições acerca de saúde mental no trabalho e fatores de risco psicossocial são "muito genéricas e com uma conotação subjetiva muito grande”. Os pesquisadores citam a situação em que um paciente narra ao médico uma série de sentimentos, sensações e disfunções físicas ou psicológicas que descrevem uma patologia que o médico já conhece, ou seja, “os sintomas descritos pelo paciente não são aparentes ou ilusão do paciente. Pelo contrário, são muito reais e destruidores de sua saúde":

Então o médico diagnostica que esse paciente chegou ao seu consultório "com uma série de queixas" que demonstram que ... não consegue realizar as suas atividades normais de maneira satisfatória, nem de trabalhar de forma produtiva e frutífera. Ele, paciente, se sente inapto para corresponder às exigências ou às expectativas que lhes são exigidas no dia a dia. Esse é o diagnóstico médico. Um médico compreende perfeitamente esse conceito. (PENIDO; PERONE, 2013, p. 39)

18 A Organização Mundial da Saúde (OMS) incluiu a síndrome de burnout, caracterizada pelo esgotamento profissional, na próxima Classificação Internacional de Doenças (CID-11) com o Código QD85: "Problemas associados ao emprego ou ao desemprego".

Laborare. Ano II, Número 3, Jul-Dez/2019, pp. 106-138. ISSN 2595-847X. https://trabalhodigno.org/laborare DOI: https://doi.org/10.33637/2595-847x.2019-35 
Dessa forma, os autores concluem que há somente uma descrição literal dos sentimentos, sensações e disfunções físicas e/ou psicológicas que afligem o indivíduo naquele momento, não havendo na narrativa nenhuma interpretação pessoal.

\section{DIAGNOSTICANDO O RISCO PSICOSSOCIAL}

Será citado e analisado a seguir o que foi verificado pela auditoria fiscal do trabalho em Minas Gerais, em fiscalizações no setor bancário e em empresas de teleatendimento.

As referências utilizadas em relação ao teleatendimento são três ações fiscais realizadas em grandes empresas do setor em Minas Gerais, sendo uma, no ano de 2017, (Empresa A), uma, em 2018, (Empresa B) e a última, em 2019, (Empresa C). Duas empresas possuem mais de 4.000 trabalhadores, e a terceira, mais de 1.000 trabalhadores.

No setor bancário, será analisado o relatório da ação realizada, em 2018, pela Superintendência Regional do Trabalho de Minas Gerais junto a uma grande instituição do setor. A fiscalização alcançou 53 agências da instituição e 646 bancários, durante a qual os auditores fizeram uso de instrumentos múltiplos, incluindo análise de documentos, entrevistas semiestruturadas, observação direta, bem como a aplicação de 81 questionários junto ao universo de profissionais presentes nas agências no ato da operação. A intervenção resultou em 1.369 autos de infração, correspondendo a uma multa estimada no valor de 5,3 milhões de reais.

Todas as fiscalizações tiveram como foco, entre outras questões, a investigação das práticas de organização do trabalho adotadas pelas empresas e o adoecimento dos trabalhadores.

Chegou-se à conclusão, como se verá nos próximos tópicos, que as formas de gestão adotadas pelas empresas fiscalizadas têm como base a "gestão por estresse" e a "gestão por medo", já citadas no início desse artigo, sendo configurado o assédio moral organizacional.

No item II.1 serão apresentados os dados da fiscalização no setor bancário, e no item II. 2 no setor de teleatendimento.

\section{SETOR BANCÁRIO}

O setor bancário, assim como outros, passou por transformações nas últimas décadas, tendo que se adaptar a um cenário de maior competição e necessidade de aumento de 
lucros. Além de estarem inseridos nesse contexto, os bancos passaram por alterações decorrentes do fim do processo inflacionário, o que levou a uma alteração do foco de atuação, sendo que a venda de serviços ${ }^{19}$ para os clientes passou a ser prioridade.

Verificou-se na referida fiscalização que há realmente uma cobrança ostensiva para a realização de vendas de produtos.

É estipulada uma série de metas de produtividade, as quais são levadas em consideração para o pagamento da Remuneração Variável, sendo que cada uma delas possui um peso ou pontuação. Como exemplo, há meta de abertura de contas, de vendas de seguros, consórcios, títulos de capitalização, empréstimos, cartões etc. Para ser elegível ao recebimento da remuneração variável, o trabalhador tem um mínimo de pontos a alcançar.

Segundo o relatório da fiscalização, foi verificado que as metas cobradas são abusivas pelos seguintes motivos:

$\checkmark$ Metas são estipuladas pelo banco sem qualquer tipo de participação dos trabalhadores;

$\checkmark$ São individuais, o que leva os trabalhadores a se isolarem e concorrerem entre si;

$\checkmark$ Ritmo de trabalho intenso na busca pelo atingimento das metas, sendo que muitas vezes há necessidade de realização de horas extras para se conseguir realizar seu trabalho;

$\checkmark$ Segundo os trabalhadores, apesar de todo o esforço, nem sempre conseguem receber a remuneração variável;

$\checkmark$ Algumas metas independem dos esforços dos trabalhadores, ou fogem de sua governabilidade $^{20}$;

$\checkmark$ Vários trabalhadores reclamaram sobre o caráter, em algumas situações, pouco ético de suas atividades ${ }^{21}$;

19 Segundo Sznelwar (2011): "O bancário não é responsável apenas por prestar um bom atendimento, ele tem de vender: seguro, capitalização, previdência, cartão de crédito. E precisa fazê-lo cada vez mais e mais, para cumprir metas abusivas impostas de cima para baixo com base em um sistema de gestão de resultados". 20 Como exemplo, a ocorrência de contas inativas (aquelas que não são movimentadas por períodos longosacima de 90 dias) ou contas que são encerradas pelos clientes repercutem negativamente na meta de abertura de contas conforme já mencionado. Ou nos casos de resgastes feitos pelos clientes, que "prejudicam" as metas, fazendo com que sejam aumentadas.

21 Segundo o relatório da fiscalização, na busca pelo alcance das metas, os trabalhadores têm de oferecer (às vezes de forma insistente) para os clientes produtos que nem sempre os mesmos necessitam ou pelos quais não possuam interesse, ou produtos pouco atrativos, além de, em alguns casos, terem de condicionar o

Laborare. Ano II, Número 3, Jul-Dez/2019, pp. 106-138. ISSN 2595-847X. https://trabalhodigno.org/laborare DOl: https://doi.org/10.33637/2595-847x.2019-35 
Segundo os trabalhadores, as metas são aumentadas continuamente, nunca sendo suficiente;

$\checkmark$ As cobranças pelo cumprimento das metas são realizadas de diversas formas, sendo que muitas delas são motivos de constrangimentos e estresse por parte dos trabalhadores ${ }^{22}$;

$\checkmark$ As entrevistas realizadas com aplicação de questionários apontaram que:

$66,66 \%$ dos trabalhadores consideram as metas abusivas;

$45,45 \%$ dos trabalhadores relataram não conseguir atingir as metas habitualmente;

70\% relataram haver ameaça de demissão por não atingimento das metas.

Vale ressaltar que essa imposição de metas, sem qualquer tipo de participação dos trabalhadores, já foi denunciada pelo sindicato dos trabalhadores do setor ${ }^{23}$. No livro "Saúde dos Bancários" (2011), no capítulo intitulado "Bancários não são máquinas", em que são apresentados os resultados de pesquisa realizada com mais de 800 trabalhadores do setor, o autor conclui:

É perceptível entre a categoria que o sistema de metas imposto de cima para baixo, sem conexão com as realidades de mercado, está relacionado às práticas de assédio moral. $\mathrm{O}$ bancário identifica que as metas abusivas são o principal fator de estresse e adoecimento. (BRUNO, 2011, p. 31)

Enfim, os resultados encontrados pela físcalização são compatíveis com aqueles resultantes de pesquisa já mencionada, desenvolvida pelo Sindicato dos Bancários de São Paulo, Osasco e Região. A pesquisa relatada, no referido livro, afirma que dois terços dos bancários $(66 \%)$ acreditam que o ambiente de trabalho em que vivem pode levar ao adoecimento, e 54\% consideram que eles adoecem mais do que outras categorias profissionais, apontando a seguinte conclusão:

O resultado não é apenas preocupante. É assustador. Dos números gerais aos depoimentos colhidos nas entrevistas qualitativas, a pesquisa produz um retrato sem retoques do clima de tortura psicológica que domina as entranhas

\footnotetext{
fornecimento de algum produto à compra de outro.

22 Ainda segundo o referido relatório "as formas de cobrança pelo cumprimento das metas são as mais variadas: através de e-mails, reuniões individuais, reuniões coletivas, mensagens via WhatsApp, teleconferências, exposição dos resultados com ranqueamento dos trabalhadores etc.".

23 Pesquisa desenvolvida pelo Sindicato dos Bancários de São Paulo, Osasco e Região entre novembro de 2010 e janeiro de 2011, quando foram ouvidos 818 trabalhadores de seis das maiores instituiçōes financeiras do País: Bradesco, Itaú/Unibanco, HSBC, Santander, Caixa Econômica Federal e Banco do Brasil/Nossa Caixa.
}

Laborare. Ano II, Número 3, Jul-Dez/2019, pp. 106-138. ISSN 2595-847X. https://trabalhodigno.org/laborare DOI: https://doi.org/10.33637/2595-847x.2019-35 
do sistema bancário brasileiro, cujo ambiente de trabalho é fonte constante de medo, angústia, frustração, perseguição, desvios éticos, disputa desmedida entre os colegas e grande insegurança pessoal (BRUNO, 2011, p. 21).

Durante essa ação da auditoria fiscal do trabalho, foram ainda realizadas quatro análises de doenças do trabalho, sendo todos os casos relacionados a transtornos mentais, em especial depressão, ansiedade e síndrome do pânico. Importante também ressaltar que a despeito de não ter havido emissão de CAT (Comunicação de Acidente de Trabalho) em nenhum dos casos, todos tiveram o nexo com o trabalho estabelecido quando da perícia do INSS.

Finalizando, devido às transformações ocorridas no setor bancário, nas últimas décadas, em especial devido à imposição de metas que aumentam indefinidamente e à busca cada vez maior por produtividade, o cenário do adoecimento no setor bancário vem sofrendo mudanças. As doenças do sistema osteomuscular e do tecido conjuntivo são ainda as principais causas dos afastamentos, no entanto, os transtornos mentais vêm apresentando um preocupante e progressivo aumento.

\section{TELEATENDIMENTO}

Nas fiscalizações nas empresas de teleatendimento, verificou-se que as mesmas tendem a adotar práticas de organização do trabalho muito semelhantes, tendo como base, resumidamente, a imposição de um ritmo de trabalho acelerado, controle ostensivo (da produtividade, de pausas, do atendimento etc.), pressão por produtividade, ganhos de vantagens, vinculados à produção, entre outros critérios, que serão pontuados à frente.

O diagnóstico foi feito através de entrevistas com os trabalhadores e aplicação de questionários, além de avaliação de documentos.

Há, em geral, a exigência de uma série de metas ou indicadores, na maioria das vezes vinculada ao recebimento de remuneração variável (RV) ou ao ganho de outras vantagens, como prêmios, folgas ou promoções. Importante ressaltar que esses critérios são, em geral, pouco claros e mesmo confusos, com mudanças frequentes, sendo que os trabalhadores não sabem explicar ao certo como os mesmos funcionam, e não costumam receber por escrito essas regras. Nas entrevistas, é comum a fiscalização ouvir frases como: "Eu acho que para receber a 'variável' eu posso ter uma falta justificada", ou "Eu acho que a nota de monitoria de qualidade é de 90\%".

Serão citados alguns exemplos, porém o tema não será esgotado, pois não se entrará nos detalhes, por exemplo, da cobrança do atendimento estrito ao script ou roteiros de

Laborare. Ano II, Número 3, Jul-Dez/2019, pp. 106-138. ISSN 2595-847X. https://trabalhodigno.org/laborare DOI: https://doi.org/10.33637/2595-847x.2019-35 
atendimento, do TMA ${ }^{24}$ (Tempo Médio de Atendimento), das monitorias, quando são avaliadas as ligações em vários aspectos, e ainda, não será abordada a ausência de uma avaliação adequada dos riscos presentes à saúde dos trabalhadores, entre outros.

Vale ressaltar que o Anexo II, da NR $17^{25}$, que trata especificamente das questões ligadas ao trabalho de teleatendimento, é comumente e reiteradamente descumprido pelas empresas.

Além do assédio moral organizacional, verificou-se, como se verá a seguir, uma série de outras condições de trabalho caracterizadas como fatores de risco psicossociais, relacionadas, tanto ao contexto do trabalho, quanto ao controle do trabalho (segundo a classificação do Health and Safe Executive- HSE do Reino Unido ${ }^{26}$ ).

Os riscos levantados relacionados ao conteúdo do trabalho foram: exposição contínua a clientes; pressão intensa para atingimento de metas (inclusive com ganho de remuneração vinculado à produtividade), metas essas, muitas vezes, inalcançáveis; intenso ritmo de trabalho, o qual é definido pelas ligações, que são distribuídas de forma automática, muitas vezes, sem qualquer tipo de pausa entre uma ligação e outra; restrição para a realização de pausas, sendo que os trabalhadores não definem quando podem fazer pausas, sendo controlados e monitorados durante todo o tempo; entre outros.

Quanto ao contexto do trabalho, verificou-se que os salários são em geral baixos (em alguns casos, inferior ao salário mínimo nacional); o setor apresenta alta taxa de rotatividade (não sendo diferente nas empresas fiscalizadas), com ameaças de demissão e aplicação de medidas disciplinares por motivos banais, com utilização de "escala pedagógica" 27 ; falta de controle sobre o próprio trabalho, uma vez que há fraseologias (script) a serem utilizadas, e um tempo médio de duração das ligações a ser atendido; entre outros.

\section{VIGILÂNCIA}

Entre as práticas de organização do trabalho adotadas pela empresa está o controle dos trabalhadores, que é realizado de maneira ostensiva, sendo utilizado de diversas formas: o controle visual (em muitas empresas o posto de trabalho do supervisor é

24 O TMA é o tempo máximo que o trabalhador pode "gastar" em cada ligação, que, por ser muito exíguo, é um dos indicadores, juntamente com a nota de qualidade (monitoria), que mais impacta no não recebimento do valor total da RV, conforme relatório da fiscalização da Empresa C. 25 Portaria MTE nº 9 de 30/03/2007. Anexo II da Norma Regulamentadora- NR 17.

26 Cox (1993), citado por Baruki (2018), resumiu os riscos psicossociais em duas categorias, conteúdo do trabalho e contexto do trabalho, subdividindo-as em nove classes (HSE).

27 Escala de punições relativas a determinadas condutas do operador, com aumento gradativo das penas na medida em que há repetição das condutas puníveis, podendo chegar à demissão por justa causa.

Laborare. Ano II, Número 3, Jul-Dez/2019, pp. 106-138. ISSN 2595-847X. https://trabalhodigno.org/laborare DOl: https://doi.org/10.33637/2595-847x.2019-35 
mais alto do que dos trabalhadores de sua equipe); o monitoramento feito em tempo real de cada um dos membros da equipe (na tela do monitor fica exposto o que cada um dos operadores está fazendo, se está atendendo, se está em pausa, qual tipo de pausa, por quanto tempo, como está cada um dos indicadores ou metas, duração da ligação etc.); monitoramento das ligações dos trabalhadores sem o conhecimento prévio do mesmo ${ }^{28}$; estratégias visando evitar faltas ao trabalho, mesmo as justificadas (com atestados médicos por exemplo); tenta-se evitar/controlar as saídas do posto de trabalho (até mesmo para realização de necessidades físiológicas ${ }^{29}$ ); metas estipuladas muito difíceis de serem alcançadas ou mesmo inalcançáveis, conforme se verá; divulgação dos resultados de desempenho dos trabalhadores (o que é, inclusive, expressamente proibido pelo item $5.3^{30}$ do Anexo II da NR 17) etc.

\section{CONTROLE DE FALTAS JUSTIFICADAS}

As empresas utilizam mecanismos para evitar que os trabalhadores faltem ao trabalho, mesmo tratando-se de faltas justificadas, como por exemplo, em caso de adoecimento. Em alguns casos é estipulada uma "meta" para faltas justificadas e, em outros casos, as faltas justificadas funcionam como "deflator", ou seja, há um desconto na remuneração variável final que o trabalhador iria receber. Veja a seguir como isso funciona em cada uma das empresas analisadas.

\section{Empresa A:}

Na empresa A, para receber $100 \%$ da remuneração variável, o trabalhador não podia ter faltas justificadas, chamadas no quadro a seguir de "absenteísmo". Verifique-se que o absenteísmo se refere às faltas justificadas, uma vez que para a falta injustificada, conforme o quadro, o trabalhador sequer será elegível para o recebimento da RV:
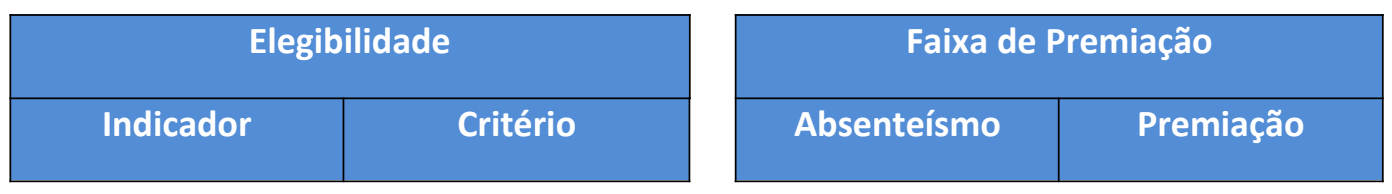

\footnotetext{
28 item 5.12 do Anexo II da NR 17 prevê: "A utilização de procedimentos de monitoramento por escuta e gravação de ligações deve ocorrer somente mediante o conhecimento do operador".

29 O item 5.7 do Anexo II da NR 17 diz: "Com o fim de permitir a satisfação das necessidades fisiológicas, as empresas devem permitir que os operadores saiam de seus postos de trabalho a qualquer momento da jornada, sem repercussões sobre suas avaliações e remunerações".

30 Item 5.13: "É vedada a utilização de métodos que causem assédio moral, medo ou constrangimento, tais como: a) estímulo abusivo à competição entre trabalhadores ou grupos/equipes de trabalho; b) exigência de que os trabalhadores usem, de forma permanente ou temporária, adereços, acessórios, fantasias e vestimentas com o objetivo de punição, promoção e propaganda; c) exposição pública das avaliações de desempenho dos operadores".
}

Laborare. Ano II, Número 3, Jul-Dez/2019, pp. 106-138. ISSN 2595-847X. https://trabalhodigno.org/laborare DOI: https://doi.org/10.33637/2595-847x.2019-35 


\begin{tabular}{|c|c|c|c|}
\hline Dias ativos & $>=20$ & $0 \%$ & $100 \%$ \\
\hline Absenteísmo & $<=4 \%$ & $0,1 \%$ a $3,5 \%$ & $80 \%$ \\
\hline Falta injustificada & $=0$ & $3,6 \%$ a $4,0 \%$ & $50 \%$ \\
\hline TMA $<=$ & Meta & $>4 \%$ & $0 \%$ \\
\hline
\end{tabular}

\section{Empresa B:}

$\mathrm{Na}$ empresa $\mathrm{B}$, há um desconto na produção do trabalhador em caso de faltas justificadas. Há uma "tolerância" de um dia de falta justificada, mas se a falta for superior a um dia já são feitos descontos, e no caso de ser maior ou igual a três dias, há um desconto de $100 \%$ :

\begin{tabular}{|ccc|}
\hline \multicolumn{3}{c|}{ DESCONTO POR FALTA } \\
\hline CAMPANHA & ESCALA & META/DIA \\
\hline Justificado & até 1 faltas & $0 \%$ \\
Justificado & até 2 faltas & $50 \%$ \\
Justificado & $>=3$ faltas & $100 \%$ \\
Injustificado & $>=1$ falta & $100 \%$ \\
\hline
\end{tabular}

\section{Empresa C:}

Na empresa $C$, uma das metas utilizadas, cujo nome não será citado visando preservar a identidade da empresa, calcula o tempo que foi pago ao trabalhador em relação ao tempo que ele ficou logado ao sistema da empresa (ou seja, o tempo que foi pago sem ele estar trabalhando). O cálculo é realizado da seguinte forma: total de horas logadas dividido pelo total de horas que foram pagas ao trabalhador. Entram nesse cálculo as faltas justificadas (horas que foram pagas, já que se trata de falta justificada, mas o trabalhador, obviamente, não se encontrava logado). A meta para o trabalhador receber o valor total da parcela da RV referente a esse critério é $97 \%$. Essa meta corresponde a poucas horas, sendo que, se o trabalhador faltar um dia, ele já deixará de receber a parcela referente a esse indicador.

\section{CONTROLE DE SAÍDAS DO POSTO DE TRABALHO}

As empresas utilizam diferentes maneiras de fazer o controle das saídas do posto de trabalho, criando "metas", "indicadores" com diferentes nomes para esse fim, e têm na tela 
do monitor, não só todo o desempenho de cada um dos operadores, mas se os mesmos estão em sua PA, se estão atendendo, se estão em pausa, qual o tipo de pausa etc.

Há ainda o controle visual feito pelo supervisor e, às vezes, pelos coordenadores e gerentes, uma vez que os operadores ficam dispostos em filas, de forma que seus gestores podem acompanhar se eles estão em seus postos de trabalho ou não.

\section{Empresa A:}

Para ser elegível ao recebimento da RV, em determinado setor da empresa, o operador deve ter $99 \%$ do seu tempo logado como "tempo produtivo", que é o tempo em que ele está efetivamente em atendimento. Para o cálculo desse "tempo produtivo", são descontados os 40 minutos de pausas previstas na NR 17 (duas pausas de 10 minutos para descanso e uma de vinte minutos para lanche). Sobram ainda nove minutos. Esses minutos seriam para atrasos e para a pausa para ir ao banheiro, que é registrada como pausa "particular". Se for ultrapassada, o operador não se torna elegível para o recebimento da RV. Veja o item "elegibilidade" no quadro abaixo:

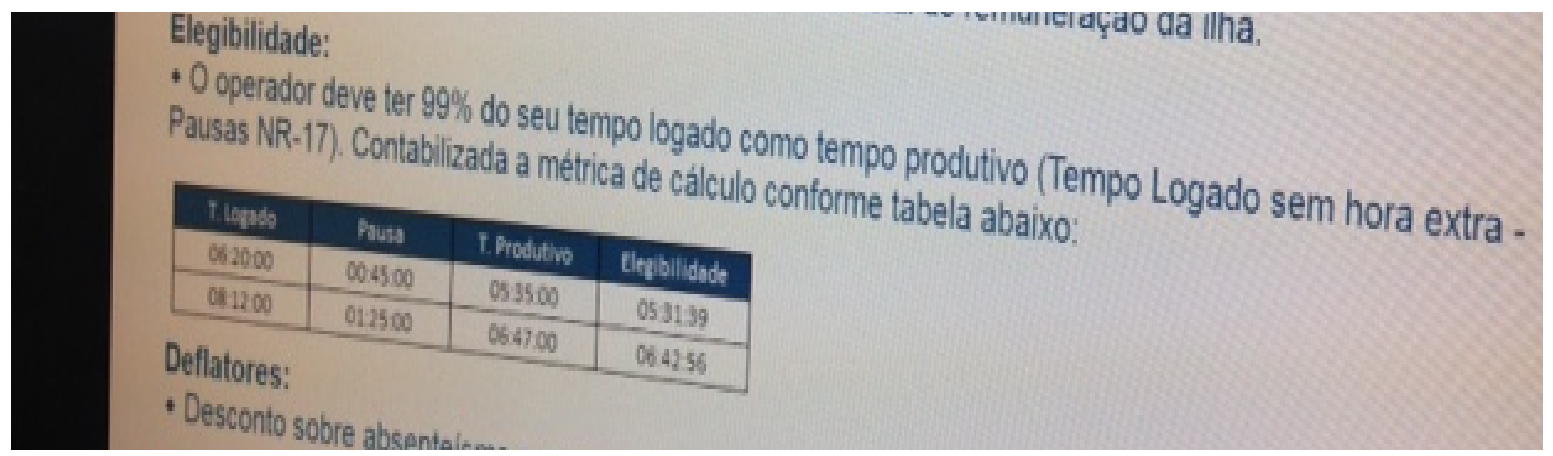

A foto a seguir, da tela do computador, mostra que o operador ficou com 97,3\% de tempo produtivo (não alcançando os 99\%), e mostra também que o que impactou nesse percentual foi a pausa "particular" (banheiro), que foi de 11 minutos e 34 segundos (repare o destaque em vermelho). Fica, dessa forma, claro, que a empresa estipula um tempo limite para as idas ao banheiro: 


\begin{tabular}{|c|c|c|c|c|c|c|c|c|c|}
\hline \multirow[b]{2}{*}{$\begin{array}{l}\text { Meta } \\
\text { adviluo }\end{array}$} & \multirow[b]{2}{*}{ Produtivo } & \multirow[b]{2}{*}{ (C) Produtivo } & \multicolumn{3}{|c|}{ Pausa } & \multirow[b]{2}{*}{ Padilo } & \multirow[b]{2}{*}{ Lanche } & \multirow[b]{2}{*}{ Desoanso } & \multirow[b]{2}{*}{ Partioular } \\
\hline & & & Planelado & Real & NR17 & & & & \\
\hline $66+7700$ & 0604.16 & $896 \%$ & 012000 & 021436 & 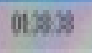 & 00020 & 00.5062 & cotesis & 02210 \\
\hline 064700 & 052739 & $805 \%$ & 013000 & 00011 & 024321 & 000555 & 010252 & 01301 & 000627 \\
\hline $06+7700$ & $0700: 2$ & $m e \%$ & 013000 & 91510? & 010090 & 00000 & 001231 & 001751 & 60000 \\
\hline 05300 & (5):3707 & $1006 \%$ & 005000 & 005719 & 6045 & 000000 & 001902 & 00188 & 0000.4 \\
\hline 053500 & 053553 & $002 \pi$ & 005000 & 01013 & 04028 & w000 & coses & 00727 & 600405 \\
\hline 05500 & $0533 \times 2$ & mor & 05000 & 001722 & 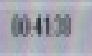 & 00000 & 00054 & conn & 000433 \\
\hline 085800 & 05858 & 97,34 & 005000 & 005913 & 05208 & $\omega 0120$ & 00.20 .36 & 00.1956 & $0011: 34$ \\
\hline 62500 & $0: 392$ & $3,5 \%$ & 005000 & $420 x$ & 01257 & $000 x$ & 002035 & 90713 & 000512 \\
\hline $0 \times 500$ & $\cos 2 x$ & $995 \%$ & 005000 & 005720 & $(0.456)$ & 000038 & coser & CORB & $00 \mathrm{all} H$ \\
\hline
\end{tabular}

\section{Empresa B:}

Segundo relatório de fiscalização, um dos critérios utilizados pelo empregador para o pagamento da remuneração variável é o "tempo disponível do operador", cuja meta é estipulada em $5 \mathrm{hs}$ e $20 \mathrm{~min}$, para jornadas de $6 \mathrm{hs}$ e $20 \mathrm{~min}$. A empresa utiliza um nome específico para esse critério, no entanto, ele não será citado aqui para que a identidade da empresa seja preservada.

O "tempo disponível" é o "tempo logado" menos as "pausas". As pausas englobam o intervalo de 20min para alimentação/descanso ("lanche") e as duas pausas de $10 \mathrm{~min}$ ("descanso"), previstas na Norma Regulamentadora N.17. Subtraindo essas pausas, restam, dessa forma, 20 minutos, que o trabalhador utiliza para toda as outras pausas ("feedback", treinamento, "sistema" etc.), inclusive a "particular".

\section{Empresa C:}

A empresa $\mathrm{C}$ também utiliza um critério (cujo nome não será citado a fim de preservar a identidade da empresa) com o objetivo de mensurar as pausas feitas pelo trabalhador. A fórmula para se calcular esse critério é a seguinte: horas disponíveis para atendimento divididas pelas horas logadas.

Segundo entrevistas com prepostos da empresa (supervisores, gestores e equipe do setor de planejamento), somente as pausas chamadas "treinamento", e "ambulatório" e o intervalo para lanche não entram nessa conta. As outras pausas, que podem ser colocadas no sistema, como, pausas descanso (duas pausas de 10 minutos), pausa feedback, e inclusive a pausa "particular", utilizada para satisfação de necessidades fisiológicas (para ir ao banheiro ou beber água), são somadas ao se aplicar a fórmula. A meta para esse critério é de $90 \%$. Esse valor corresponde a 38 minutos no caso da

Laborare. Ano II, Número 3, Jul-Dez/2019, pp. 106-138. ISSN 2595-847X. https://trabalhodigno.org/laborare DOl: https://doi.org/10.33637/2595-847x.2019-35 
jornada de seis horas e vinte minutos. Logo, sendo o total das duas pausas descanso (obrigatórias) de 20 minutos, restam 18 minutos para o trabalhador utilizar para todas as outras pausas, inclusive a particular.

\section{Aplicação de Medidas Disciplinares}

Nas empresas de teleatendimento, de forma geral, a aplicação de medidas disciplinares ocorre de forma corriqueira e, muitas vezes, por motivos banais.

Essa prática é motivo de muito sofrimento e angústia, nos trabalhadores, que se veem ameaçados todo o tempo, inclusive com o risco de serem demitidos por justa causa, já que é comum a utilização de uma "escala pedagógica"31.

Segundo fala de trabalhador da Empresa B:

“Eu 'tomei' um trauma dessa palavra advertência e justa causa! Trauma mesmo. É o tempo todo: é justa causa, é justa causa, é advertência, é advertência!”.

É muito comum a aplicação de penalidades por atrasos, ou mesmo a utilização dos atrasos como "deflator" (corte na RV). Veja a seguir que atrasos de cinco minutos já levam a um desconto de $15 \%$ da RV (Empresa C):

\begin{tabular}{|c|c|c|}
\hline \multicolumn{2}{|c|}{ Deflatores } \\
\hline Deflator & Meta & Desconto \\
\hline Atrasos & $00: 05: 00$ & $15,00 \%$ \\
\hline Monitoria & $79,99 \%$ & $50,00 \%$ \\
\hline
\end{tabular}

Nesse ponto, vale lembrar que as empresas consideram para cômputo da jornada o sistema login-logout, ou seja, somente o tempo efetivamente trabalhado. Não é levado em consideração o momento em que o trabalhador chega à empresa para trabalhar, como em qualquer outra atividade ou setor econômico.

O fato é que o trabalhador "chega para trabalhar" ao entrar na empresa (passa pela catraca) e, antes de ir para seu posto de trabalho, ele tem a obrigatoriedade de colocar seus objetos pessoais em um armário, se necessário vai ao banheiro ou toma água, enche a garrafinha de água, e então vai para sua PA para fazer o login e iniciar o atendimento. Somente nesse momento, quando faz o login, e inicia o atendimento, sua jornada de trabalho é considerada como iniciada. Não é incomum haver

31 Escala de punições relativas a determinadas condutas do operador, com aumento gradativo das penas na medida em que há repetição das condutas puníveis, podendo chegar à demissão por justa causa.

Laborare. Ano II, Número 3, Jul-Dez/2019, pp. 106-138. ISSN 2595-847X. https://trabalhodigno.org/laborare DOl: https://doi.org/10.33637/2595-847x.2019-35 
problemas para encontrar uma máquina que esteja funcionando adequadamente, o que pode tomar também algum tempo do trabalhador.

Importante ressaltar que, assim que chega à empresa, o trabalhador já começa a cumprir ordens determinadas pela chefia, como guardar seus pertences em armários. Inclusive, em relação à Empresa $\mathrm{C}$, há inúmeras penalizações aplicadas por "manter objetos pessoais na PA como celulares, bolsas, cadernos entre outros", e no campo "Situação-Procedimento Correto" da advertência, está descrito como o trabalhador deve proceder ao chegar à empresa:

"Funcionária deverá utilizar os escaninhos disponibilizados pela empresa para armazenar qualquer tipo de material estranho a sua atividade (tais como papel, cadernos, livro, caneta, lápis, celular, MP3, aparelhos eletrônicos entre outros)".

Segue descrição abaixo:

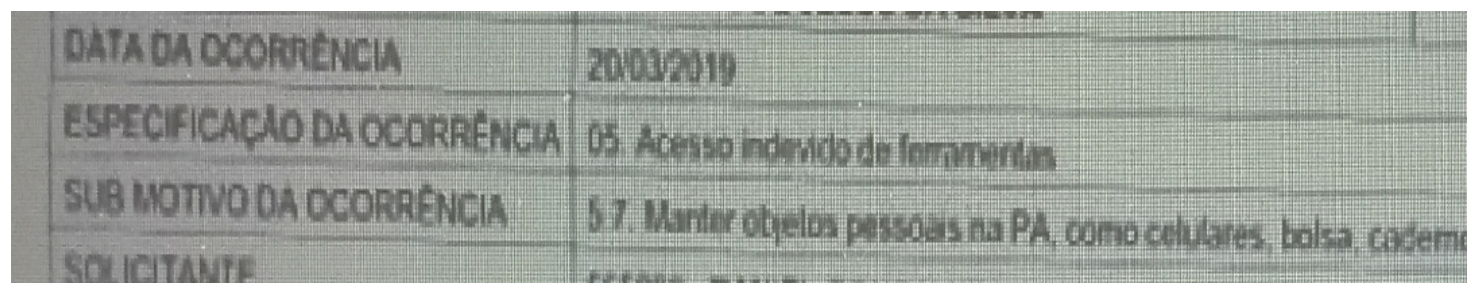

Analisando essa situação de forma literal, utilizando o raciocínio da empresa de que o trabalhador somente inicia sua jornada ao fazer o longin nos sistemas, a penalidade por não guardar seus pertences nos escaninhos ou armários, é aplicada, dessa forma, por uma irregularidade cometida pelo trabalhador antes do início de sua jornada, uma vez que a guarda de seus pertences é anterior à realização do login e início dos atendimentos.

Logo, ao "concluir" que o trabalhador "chegou atrasado", inclusive com aplicação de penalidades, como no exemplo acima, em que há cortes na RV, devido a atrasos de até cinco minutos, o empregador está se referindo ao "atraso" para logar no sistema, não levando em consideração todo esse tempo anterior, em que, inclusive, o trabalhador já se encontrava sob as ordens e comando da empresa.

São comuns também as advertências por "estouros de pausas", não havendo nenhum tipo de tolerância, havendo penalizações por "estouros", por exemplo, de três, dois, ou mesmo, de um minuto. Veja o exemplo a seguir: 
Tipo de medida: ADVERTÊNCIA

Venho por meio desta, informar que, no(s) dia(s)

$12 / 11 / 2016$

V.Sa. praticou o seguinte

ato em desacordo com as normas internas da empresa:

Não comparecer a empresa no dia citado (12/11/2016) e não apresentar justificativa legal para abono do mesmo. Alem disso no dia citado (18/09/2016) a colaboradora extrapolou seu tempo de pausa lanche, sendo um total de 20 minutos e foi realizado 21 minutos e 56 segundos, no dia 17/11/2016 extrapolou a pausa lanche sendo 20 minutos e a mesma realizou 22 minutos e 48 segundos e no dia 19/11/2016 extrapolou a pausa descanço sendo 20 minutos e a mesma realizou 22 minutos e 16 segundos. A presença e 0 cumprimento da jornada do trabalho e utilização de pausas corretamente, são essenciais à qualidade dos serviços prestados pela $\mathrm{AeC}$ aos seus clientes. A sua presença ao trabalho é muito importante para nós, além de ser um pré-requisito importante para o seu crescimento, tanto pessoal quanto profissional. Devido a isso, a $\mathrm{AeC}$ coloca à disposição de seus colaboradores vários recursos para que sejam evitadas as faltas sem injustificadas, sempre que possivel.

Advertência aplicada na Empresa A:

Veja que são citados como motivo da aplicação da penalidade estouros de pausa de dois minutos, e mesmo um minuto.

\section{Metas Inalcançáveis}

Conforme dito anteriormente, há a exigência de muitos critérios que, se alcançados, podem levar ao recebimento de remuneração variável, folgas, promoções ou outros prêmios, e que também podem levar a "sinalizações", feedbacks", 32 e mesmo advertências e suspensões. A fiscalização verificou que as metas estipuladas pelas empresas são, na maioria das vezes, muito difíceis de serem atingidas, ou mesmo, inalcançáveis.

\section{Empresa A}

Em um dos setores da Empresa A, no mês de setembro de 2016, para um total de 1.209 operadores de teleatendimento, 958 receberam algum valor de RV. Veja:

\begin{tabular}{|l|}
\hline Total RV operador: \\
\hline Beneficiados: \\
\hline Média agente: \\
\hline Menor valor: \\
\hline Maior valor: \\
\hline
\end{tabular}

\begin{tabular}{|c|}
\hline$R \$ 37.379,40$ \\
\hline 958 \\
\hline$R \$ 39,02$ \\
\hline$R \$ 0,10$ \\
\hline$R \$ 140,80$ \\
\hline
\end{tabular}

32 "Sinalizações" e "feedbacks" são formas de advertências orais, aplicadas aos operadores geralmente pelos supervisores, muito comuns no teleatendimento.

Laborare. Ano II, Número 3, Jul-Dez/2019, pp. 106-138. ISSN 2595-847X. https://trabalhodigno.org/laborare DOI: https://doi.org/10.33637/2595-847x.2019-35 
Já no mês de maio de 2017, nesse setor, segundo dados fornecidos pela empresa e contidos no relatório de fiscalização, entre 472 operadores de teleatendimento, somente 132 receberam algum valor de RV. Ou seja, a maioria (mais de $62 \%$ dos operadores) não recebeu nenhum valor de RV.

\section{Empresa B}

Segundo o relatório de fiscalização, na Empresa B, em um dos setores com mais de 4.000 trabalhadores, em um período de 7 meses, as metas não foram alcançáveis para a grande maioria deles:

"Segundo dados fornecidos pela própria empresa, nos meses de junho a dezembro de 2017 , somente $26,02 \%$ dos trabalhadores receberam algum valor de remuneração variável, e de janeiro a julho de 2018 , somente $27,62 \%$ receberam".

Já em outro setor, com 550 trabalhadores, nos meses de junho a dezembro de 2017, somente $34,78 \%$ dos trabalhadores receberam algum valor de remuneração variável, e de janeiro a julho de 2018 , somente $24,12 \%$ receberam algum valor, segundo o mesmo relatório.

\section{Empresa C}

Em relação à Empresa $\mathrm{C}$, verificou-se que as metas não são alcançáveis para a grande maioria dos trabalhadores. Conforme a tabela a seguir, uma ínfima parcela dos trabalhadores consegue receber o valor total da remuneração variável- RV.

Como exemplo, em um determinado setor, com uma média de 240 trabalhadores elegíveis ao recebimento da RV, analisando-se os dados referentes a seis meses (outubro, novembro e dezembro de 2018 e janeiro, fevereiro e março de 2019), chegou-se ao resultado apontado na tabela a seguir.

\begin{tabular}{|c|c|c|}
\hline \multirow[t]{2}{*}{ MESES } & \% TRABALHADORES & \multirow{2}{*}{$\begin{array}{c}\text { \% TRABALHADORES NÃO RECEBEU } \\
\text { NENHUM VALOR DE RV }\end{array}$} \\
\hline & RECEBEU VALOR TOTAL RV & \\
\hline OUTUBRO & ZERO & $17,5 \%$ \\
\hline NOVEMBRO & ZERO & $7,37 \%$ \\
\hline DEZEMBRO & $3,3 \%$ & $5,5 \%$ \\
\hline JANEIRO & $23,2 \%$ & $12,5 \%$ \\
\hline FEVEREIRO & $16,6 \%$ & $14,4 \%$ \\
\hline MARÇO & $15 \%$ & $8,8 \%$ \\
\hline $\begin{array}{l}\text { MÉDIA } 6 \\
\text { MESES }\end{array}$ & $9,6 \%$ & $11 \%$ \\
\hline
\end{tabular}

Laborare. Ano II, Número 3, Jul-Dez/2019, pp. 106-138. ISSN 2595-847X. https://trabalhodigno.org/laborare DOI: https://doi.org/10.33637/2595-847x.2019-35 
Em resumo:

Uma parcela irrisória dos trabalhadores consegue receber o valor total da RV. Segundo a tabela acima, somente $9,6 \%$ do total conseguiram receber, ou seja, dos 242 trabalhadores, somente 23 conseguiram receber o valor total. A grande maioria, ou recebe valores inferiores ao total, ou não recebe nenhum valor. De acordo com a tabela acima, $11 \%$ dos trabalhadores não recebem nenhum valor.

Em outro setor, com 150 trabalhadores, em relação às metas estipuladas, verificou-se que as mesmas não são alcançáveis para a grande maioria. Segundo dados fornecidos pela própria empresa, nos meses de janeiro de 2018 a março de 2019 , somente $27 \%$ dos trabalhadores receberam a $\mathrm{RV}$. Ou seja, $73 \%$ dos empregados não receberam qualquer quantia de RV. Veja o quadro a seguir:

\begin{tabular}{|c|c|c|c|c|}
\cline { 3 - 5 } \multicolumn{1}{c|}{} & Quadro & Receberam & $\%$ \\
\cline { 2 - 5 } & JAN & 125 & 32 & $26 \%$ \\
\cline { 2 - 5 } & FEV & 137 & 40 & $29 \%$ \\
\cline { 2 - 5 } & MAR & 131 & 37 & $28 \%$ \\
\cline { 2 - 5 } & ABR & 131 & 41 & $31 \%$ \\
\cline { 2 - 5 } & MAI & 135 & 47 & $35 \%$ \\
\cline { 2 - 5 } & JUN & 150 & 37 & $25 \%$ \\
\cline { 2 - 5 } & JUL & 151 & 34 & $23 \%$ \\
\cline { 2 - 5 } & AGO & 142 & 35 & $25 \%$ \\
\cline { 2 - 5 } & SET & 143 & 39 & $27 \%$ \\
\cline { 2 - 5 } & OUT & 140 & 45 & $32 \%$ \\
\cline { 2 - 5 } & NOV & 140 & 33 & $24 \%$ \\
\cline { 2 - 5 } & DEZ & 138 & 33 & $24 \%$ \\
\hline \multirow{3}{*}{2019} & JAN & 141 & 27 & $26 \%$ \\
\cline { 2 - 5 } & FEV & 147 & 38 & $27 \%$ \\
\hline & MÉDIA & 139 & 37 & \\
\hline
\end{tabular}

\section{Conclusão em relação ao diagnóstico do risco psicossocial}

Enfim, o que se observa, segundo os referidos relatórios de fiscalização, é que, a partir da análise minuciosa da organização do trabalho praticada por essas empresas, restou configurado o assédio moral organizacional.

No relatório da fiscalização da Empresa B, consta como conclusão da análise da organização do trabalho que, "com o objetivo de alcançar maior eficácia e produtividade, a empresa se utiliza de vários métodos e práticas de organização do trabalho que tem como consequência para os trabalhadores o assédio moral, medo e constrangimento". (p.23). 
Semelhante conclusão verificada na fiscalização dos bancos. O relatório diz que, tendo em vista o que foi constatado pela fiscalização, "em especial em relação às práticas de gestão adotadas pela empresa, como cobrança de metas abusivas e estratégias utilizadas para aumento de produtividade", restou configurado o assédio moral organizacional (p.12).

Chama atenção ainda o caráter pouco ético de determinadas metas estipuladas pelas empresas. Como exemplo, no caso do banco fiscalizado, conforme já descrito, os trabalhadores, muitas vezes, são obrigados a ofertar produtos pouco atrativos, ou produtos os quais nem sempre os clientes têm interesse ou mesmo necessitam e, em alguns casos, se veem obrigados a condicionar o fornecimento de algum produto à compra de outro.

E no caso das empresas de teleatendimento fiscalizadas, citamos, como exemplo, o controle realizado sobre as faltas justificadas, sendo que, além de ser realizado um controle sobre as mesmas, muitas vezes são estipuladas metas para esses tipos de faltas.

Por fim, de acordo com o que foi relatado nos itens II.1 e II.2, além da caracterização do assédio moral organizacional, vários outros riscos psicossociais foram verificados nos locais inspecionados, riscos esses relacionados tanto ao conteúdo quanto ao contexto do trabalho.

\section{CONSIDERAÇÕES FINAIS}

A auditoria fiscal do trabalho (AFT) tem como prerrogativa a verificação do cumprimento das disposições legais e regulamentares no âmbito das relações de trabalho e de emprego, inclusive as relacionadas à segurança e à saúde no trabalho ${ }^{33}$. Isso envolve, dentre outros fatores, a realização de inspeções nos locais de trabalho, entrevistas com trabalhadores, empregadores e prepostos, e verificação de todos os documentos necessários ao exercício das atribuições dos auditores fiscais do trabalho.

Dessa forma, importante ressaltar, inicialmente, que a AFT tem um papel essencial e talvez único na análise da organização do trabalho nos ambientes laborais ${ }^{34}$. As

33 O Artigo 1o do Regulamento de Inspeção do Trabalho (RIT) - Decreto no 4552, de 27/12/2002 prevê que a Inspeção do Trabalho tem por finalidade assegurar, em todo o território nacional, a aplicação das disposições legais, incluindo as convenções internacionais ratificadas, os atos e decisões das autoridades competentes e as convenções, acordos e contratos coletivos de trabalho, no que concerne à proteção dos trabalhadores no exercício da atividade laboral.

34 A avaliação da organização do trabalho de forma detalhada é passível de fiscalização, conforme prevê o item 17.6.1. 17.6.2 da NR 17. Item 17.6.1: A organização do trabalho deve ser adequada às características psicofisiológicas dos trabalhadores e à natureza do trabalho a ser executado. Item 17.6.2: A organização do trabalho, para efeito desta NR, deve levar em consideração, no mínimo: a) as normas de produção; b) o modo operatório; c) a exigência de tempo; d) a determinação do

Laborare. Ano II, Número 3, Jul-Dez/2019, pp. 106-138. ISSN 2595-847X. https://trabalhodigno.org/laborare DOl: https://doi.org/10.33637/2595-847x.2019-35 
práticas de gestão adotadas pelas empresas, muitas vezes, não são transparentes, exigindo um trabalho minucioso para a realização de um diagnóstico preciso, inclusive para a verificação da presença do assédio moral decorrente dessas práticas, como se viu nas fiscalizações citadas nesse artigo.

Tendo em vista as fiscalizações que foram objeto desse trabalho, em especial no que diz respeito à cobrança de metas, muitas vezes abusivas, atreladas ao pagamento de remuneração variável ou outras vantagens, e às formas ostensivas de controle do trabalho e trabalhadores, verifica-se que questões éticas ou morais não servem de empecilhos ou limites quando o objetivo é a intensificação do trabalho e o aumento da produtividade e do lucro.

Os limites instituídos pelas normas constitucionais, como os valores sociais do trabalho e a dignidade da pessoa humana (Constituição Federal/1988, art. $1^{\circ}$, inciso III e IV, e art. $7^{\circ}$, inciso XXII), e pelas Normas Regulamentadoras ${ }^{35}$, em especial a NR 17, ao tratar de organização do trabalho, não são cumpridos ou respeitados.

No caso do setor de teleatendimento, o Anexo II da NR 17 é bastante incisivo em relação a essas questões, estabelecendo uma série de "barreiras" que, se respeitadas, implicariam em significativas alterações nos ambientes de trabalho. O referido Anexo estabelece que as metas e remuneração variável devem ser compatibilizadas com as condições de trabalho e tempo oferecidos, e que os programas preventivos (programas que devem ser elaborados pelas empresas visando a promoção e preservação da integridade física dos trabalhadores) devem verificar as repercussões à saúde dos trabalhadores decorrentes dos sistemas de avaliação para efeito de remuneração e vantagens de qualquer espécie ${ }^{36}$.

A referida norma veda ainda a utilização de métodos que causem assédio moral, medo ou constrangimento ${ }^{37}$.

conteúdo de tempo; e) o ritmo de trabalho; f) o conteúdo das tarefas.

35 As Normas Regulamentadoras (NR) são disposições complementares ao capítulo V da CLT ("Da Segurança e da Medicina do Trabalho"), consistindo em obrigações, direitos e deveres a serem cumpridos por empregadores e trabalhadores com o objetivo de garantir trabalho seguro e sadio, prevenindo a ocorrência de doenças e acidentes de trabalho.

36 Item 5.10 do Anexo II da NR 17: 5.10. Para fins de elaboração de programas preventivos devem ser considerados os seguintes aspectos da organização do trabalho: $a$ ) compatibilização de metas com as condições de trabalho e tempo oferecidas; b) monitoramento de desempenho; c) repercussões sobre a saúde dos trabalhadores decorrentes de todo e qualquer sistema de avaliação para efeito de remuneração e vantagens de qualquer espécie; d) pressões aumentadas de tempo em horários de maior demanda; e) períodos para adaptação ao trabalho.

37 5.13. É vedada a utilização de métodos que causem assédio moral, medo ou constrangimento, tais como: a) estímulo abusivo à competição entre trabalhadores ou grupos/equipes de trabalho; b) exigência de que os trabalhadores usem, de forma permanente ou temporária, adereços, acessórios, fantasias e vestimentas com o objetivo de punição, promoção e propaganda; c) exposição pública das avaliações de desempenho dos operadores.

Laborare. Ano II, Número 3, Jul-Dez/2019, pp. 106-138. ISSN 2595-847X. https://trabalhodigno.org/laborare DOI: https://doi.org/10.33637/2595-847x.2019-35 
Enfim, várias dessas graves infrações, que podem resultar em sofrimento e adoecimento dos trabalhadores, estão abrangidas pelas Normas Regulamentadoras$\mathrm{NR}$, porém há um reiterado descumprimento das mesmas, e infelizmente, uma enorme tolerância a esse descumprimento, o que não é incomum em se tratando de legislação trabalhista.

Atualmente, mais que tolerância ao descumprimento, vem ocorrendo um verdadeiro desmonte de tudo que diz respeito à legislação trabalhista. Isso em um país que ocupa a quarta posição no ranking mundial de acidentes de trabalho ${ }^{38}$. Desde o progressivo sucateamento do Ministério do Trabalho até seu recente fim ${ }^{39}$, a reforma trabalhista (Lei 13.467/2017) com drástica redução de direitos dos trabalhadores ${ }^{40}$, e as sucessivas tentativas de modificações e reduções das $\mathrm{NR}^{41}$, são alguns exemplos.

Importante destacar o papel dessas NR na prevenção de acidentes e adoecimentos relacionados ao trabalho. Segundo um estudo realizado, em 2018, pelo Departamento de Saúde e Segurança no Trabalho, do extinto Ministério do Trabalho, as Normas Regulamentadoras ajudaram a evitar 8 milhões de acidentes de trabalho e 46 mil mortes entre as décadas de 1970 e 2010.

Para finalizar, citamos Souto Maior (2016) que, ao discorrer sobre o discurso recorrente e falacioso dos apoiadores da "flexibilização" da legislação trabalhista, de que se deve copiar os países desenvolvidos, pontua que seria necessário atrair o mesmo nível de respeito à legislação trabalhista de países como França, Alemanha, Bélgica, Luxemburgo etc., em que ela é entendida culturalmente como uma legislação relevante e essencial à preservação do modo de produção capitalista e da dignidade humana ${ }^{42}$.

38Segundo o site https:/www.anamt.org.br/portal/2018/04/19/brasil-e-quarto-lugar-no-ranking-mundial-deacidentes-de-trabalho/ (acesso em 19/07/19), o Brasil é hoje o país onde a cada 48 segundos acontece um acidente de trabalho e a cada $3 \mathrm{~h} 38$ um trabalhador perde a vida pela falta de uma cultura de prevenção à saúde e à segurança do trabalho.

39 A Medida Provisória 870/19 de 01/01/2019 determinou a extinção do Ministério do Trabalho.

40 Entre os inúmeros questionamentos referentes à reforma trabalhista, segundo 0 site http://agenciabrasil.ebc.com.br/economia/noticia/2019-06/oit-volta-analisar-reforma-trabalhista-brasileira (acesso em 16/07/2019), a Comissão de Aplicação de Normas da Organização Internacional do Trabalho (OIT) voltou a analisar, a partir de junho de 2019, a denúncia de que a reforma trabalhista fere a Convenção 98 (que estabelece regras de proteção aos direitos de trabalhadores) da agência multilateral da Organização das Nações Unidas (ONU), da qual o Brasil é signatário. Em 2018, o Brasil havia sido incluído entre os 24 casos suspeitos de violar as normas internacionais.

$41 \mathrm{Em}$ maio de 2019, o Presidente da República Jair Bolsonaro anunciou através de redes sociais que "o governo promoverá redução de $90 \%$ nas Normas Regulamentadoras (NR) de segurança e saúde no trabalho vigentes no país".

42 Ainda segundo Souto Maior (2016): "No Brasil, o número recorde de reclamações trabalhistas, 4 milhões ao ano, não se dá por complicadores da legislação e sim pela prática reiterada e deliberada de descumprimento da legislação, que é alimentada e até incentivada pela atitude complacente e amistosa da Justiça do Trabalho frente ao descumpridor da lei e favorecida pelo sucateamento a que foi submetido o Ministério do Trabalho desde a década de $60 "$.

Laborare. Ano II, Número 3, Jul-Dez/2019, pp. 106-138. ISSN 2595-847X. https://trabalhodigno.org/laborare DOl: https://doi.org/10.33637/2595-847x.2019-35 


\section{REFERÊNCIAS}

Antunes, Ricardo (2013). Os Sentidos do Trabalho. São Paulo. Boitempo.

Araújo, A. R. (2016). A organização do trabalho como fator de adoecimento. In: Macêdo, Kátia Barbosa et al. (org.). Organização do trabalho e adoecimento - uma visão interdisciplinar. Goiânia: Ed. da PUC Goiás.

Baruki, L. V. (2018). Riscos Psicossociais e Saúde Mental do Trabalhador. 2. ed. São Paulo: Editora: LTr.

Brasil. (2016) TST. Transtornos Mentais, o acidente de trabalho que ninguém vê. Disponível em: tst.jus.br/noticia-destaque/-/asset_publisher/NGo1/content/id/24289997 Acesso em: 02 fev. 2018.

Brasil. (2017) $1^{\circ}$ Boletim Quadrimestral sobre Beneficios por Incapacidade. Disponível em: http://sa.previdencia.gov.br/site/2017/04/1\%C2\%BA-boletimquadrimestral.pdf Acesso em: 12 jul. 2019.

Bruno, W. P. (2011). Bancários não são máquinas. In: Sznelwar, L. I. Saúde dos bancários. 1. ed. São Paulo: Publisher Brasil : Editora Gráfica Atitude Ltda.

Cimbalista, S. (2006). Reflexões sobre o trabalho e a subjetividade de trabalhadores resilientes sob o sistema de produção flexível. Disponível em: revistafae.fae.edu/revistafae/article/view/359/246. Acesso em: 12 set. 2019.

Cimbalista, S. (2010). Subjetividade e resiliência: o cotidiano adverso do trabalho flexível. Disponível em https://docplayer.com.br/11440202-Subjetividade-eresiliencia-o-cotidiano-adverso-do-trabalho-flexivel.html. Acesso em 11/09/2019. Acesso em: 12 set. 2019.

Costa, L. S.; Santos, M. (2013). Fatores Psicossociais de Risco no Trabalho: Lições Aprendidas e Novos Caminhos. International Journal on Working Conditions, v. $1, \mathrm{n}$. 5, p. 39-58.

Esteves (2013). Avaliação e Diagnóstico dos Riscos Psicossociais numa Loja Hipermercado. Disponível em: https://sigarra.up.pt/fpceup/pt/pub_geral.show_file? pi_gdoc_id $=568698$. Acesso em: 15 set. 2017.

Eu-Osha (Agência Europeia para a Segurança e Saúde no Trabalho). Riscos Psicossociais e Estresse no Trabalho. Disponível em: https://osha.europa.eu/pt/themes/ psychosocial-risks-and-stress. Acesso em: 12 jul. 2019.

Guedes, L. (2007). Ética no Capitalismo Contemporâneo das Finanças Mundializadas. Monografia (Graduação em Ciências Econômicas) - FAAP, São Paulo.

Guillant, L. (1956). A neurose das telefonistas. Revista Brasileira de Saúde Ocupacional, São Paulo: RBSO. (Obra original publicada pela La Presse médicale,

Laborare. Ano II, Número 3, Jul-Dez/2019, pp. 106-138. ISSN 2595-847X. https://trabalhodigno.org/laborare DOI: https://doi.org/10.33637/2595-847x.2019-35 
com o título La névrose des téléphonistes), v. 47, n. 12, p. 7-11. 1984. Disponível em: https://www3.fmb.unesp.br/7/pluginfile.php/.../ Acesso em: 19 jul. 2019.

Guimarães, L. A. M. (2013). Fatores de Riscos Psicossociais no Trabalho. In: Ferreira, Januário Justino (coord.). Saúde mental no trabalho: coletânea do fórum de saúde e segurança no trabalho do Estado de Goiás. Goiânia : Cir Gráfica.

Hirata, H. (2011). Tendências recentes da precarização social e do trabalho: Brasil, França, Japão. Caderno $C R H$, v. 24, n. 1, p. 15-22. Disponível em: http://www.scielo.br/scielo.php? pid=S010349792011000400002\&script=sci_abstract\&tlng-pt. Acesso em: 15 set. 2017.

Lacaz, F. A. C. (2016). Trabalho e Saúde em Tempos de Globalização. In: Macêdo, Kátia Barbosa et al. Organização do trabalho e adoecimento - uma visão interdisciplinar. Goiânia: Ed. da PUC Goiás. Disponível em: https://site.medicina.ufmg.br/osat/wp-content/uploads/sites/72/2017/06/Livroorganiza\%C3\%A7\%C3\%A. Acesso em: 11 jul. 2019.

Lucca, S. R.; Sobral, R. C. (2017). Aplicação de instrumento para o diagnóstico dos fatores de risco psicossociais nas organizações Disponível em: http://www.rbmt.org.br/details/214/pt-BR/aplicacao-de-instrumento-para-o-diagnosticodos-fatores-de-risco-psicossociais-nas-organizacoes. Acesso em: 20 set. 2019.

Merlo, A. R. C. (2016). Sofrimento Psíquico e Atenção à Saúde Mental. In: Macêdo, Kátia Barbosa et al. Organização do trabalho e adoecimento - uma visão interdisciplinar. Goiânia: Ed. da PUC Goiás.

OIT (2010). Riscos Emergentes e Novas Formas de Prevenção em um Mundo de Trabalho em Mudança. Disponível em: https://www.portaldaenfermagem.com.br/downloads/ cartilha-novas-formasprevencao-trabalho.pdf. Acesso em: 12 jul. 2019.

Penido, L. O.; Perone, G. (2013). Saúde mental no trabalho: esclarecimentos metodológicos para juristas. In: Ferreira, Januário Justino (coord.). Saúde mental no trabalho: coletânea do fórum de saúde e segurança no trabalho do Estado de Goiás. Goiânia: Cir Gráfica.

Rocha, F. L.; Hara, C.; Paprocki, J. (2015). Doença Mental e Estigma. In Revista Médica de Minas Gerais. Disponível em: ww.rmmg.org/artigo/detalhes/1876. Acesso em: 12 jul. 2019.

Silva, M. P.; Bernardo, M. H.; Souza, H. A. (2016). Relação entre saúde mental e trabalho: a concepção de sindicalistas e possíveis formas de enfrentamento. Rev. bras. saúde ocup. [online], v. 41.

Soboll, L. (2008). "Assédio moral-organizacional: uma análise da organização do trabalho”. São Paulo: Ed. Casa do Psicólogo. Disponível em: 
www.trt4.jus.br/ItemPortlet/download/.../Assedio_moral_e_organizacional. Acesso em: 01 fev. 2016.

Soboll, L. A.; Horst, A. C. (2013). O assédio moral como estratégia de gerenciamento: solicitações da forma atual de gestão. In: Silveira, M. A.; Sznelwar, L. I.; Kikuchi, L. S.; Maeno, M. (org.). Inovação para Desenvolvimento de Organizações Sustentáveis: Trabalho, Fatores Psicossociais e Ambiente Saudável. Campinas, SP: CTI (Centro de Tecnologia da Informação "Renato Archer"). Disponível em https://www.cti.gov.br/sites/default/files//images/pdf/publicacoes/ livro_3.pdf. Acesso em 31/10/2019.

Souto Maior, J. L. Ministros do Trabalho e da Casa Civil, por que não se calam $\underset{\complement}{B}$ Blog Jorge Luiz Souto Maior, 19/06/2016. Disponível em: https://www.jorgesoutomaior.com/blog/ministros-do-trabalho-e-da-casa-civil-porque-nao-se-calam. Acesso em 08 jul. 2019.

Sznelwar, L. I. (2011). Saúde dos bancários. 1. ed. São Paulo: Publisher Brasil: Editora Gráfica Atitude Ltda.

Taboada, N. G.; Legal, E.J.; Machado, N. (2006). Resiliência: em busca de um conceito. Rev. Bras. Crescimento Desenvolv. Hum., v. 16, n. 3, p. 104-113. Disponível em: http://pepsic.bvsalud.org/scielo.php?script=sci_arttext\&pid=S0104-1 2822006000300012 . Acesso em: 11 set. 2019.

Vieira, A. A.; Oliveira, C. T. F. (2017). Resiliência no trabalho: uma análise comparativa entre as teorias funcionalista e crítica. Cad. EBAPE. BR, v. 15, NE, p. 409-427.

Recebido: 22/07/2019

Revisado: 27/09/2019

Aprovado: 27/09/2019 